\title{
DE NENCATACOA A SAN LUCAS: MANTAS MUISCAS DE ALGODÓN COMO SOPORTE PICTÓRICO EN EL NUEVO REINO DE GRANADA.
}

\author{
LAURA LILIANA VARGAS MURCIA \\ Universidad de los Andes. Bogotá
}

\begin{abstract}
Resumen
Desde tiempos prehispánicos, los indígenas muiscas (Altiplano Cundiboyacense, Colombia) tejieron mantas de algodón, su producción continuó durante el periodo virreinal y uno de sus usos fue el de soporte para pintura de caballete. El presente artículo analiza las continuidades y los cambios técnicos de las mantas de algodón muiscas antes y después de la Conquista, relacionándolos con los contextos sociales de cada periodo.
\end{abstract}

\section{Palabras clave}

mantas muiscas, soporte pictórico de algodón, arte virreinal, pintura colonial, Nuevo Reino de Granada.

\section{FROM NENCATACOA TO SAN LUUCAS: BLANKET MUISCAS OF COTTON AS PICTORIAL SUPPORT IN THE NEW KINGDOM OF GRANADA.}

\section{Abstract}

Since pre-Hispanic times, Muisca Indians (Altiplano Cundiboyacense, Colombia) knitted cotton cloths, their production continued during viceregal period and became support to easel painting. This paper analyses the continuities and the technical changes between Muisca cotton cloths before and after the Conquest within the social context of each period.

Key words

Muisca cloth, cotton support, viceregal art, colonial painting, New Kingdom of Granada. 


\section{Introducción: $\mathrm{El}$ adiós a los tunjos de algodón}

En 1577, numerosos tunjos de algodón fueron destruidos en la Provincia de Tunja luego de la visita en busca de ídolos llevada a cabo por Diego Hidalgo Montemayor ${ }^{1}$. En 1586, en Chiquinquirá, se extendía la noticia del milagro de la renovación de una pintura de la Virgen hecha sobre una manta de algodón tejida por indios y pintada por el español Alonso de Narváez. La más apreciada de las fibras vegetales en los pueblos muiscas seguiría siendo transformada por manos indígenas en épocas virreinales. Sus usos, significados y técnicas se conservaron en algunos aspectos pero en otros fueron variando a medida que la tecnología, la economía, la religión y el orden social de la Corona se implantaban. Las ofrendas de tunjos a la tierra para que las cosechas de algodón fueran óptimas se reemplazaron por la veneración a San Isidro Labrador, santo a quien aún hoy en día los campesinos boyacenses dedican celebraciones en su honor. La gratitud a Nencatacoa, dios que llevó el arte de hilar, tejer y pintar a los indios, debió ser manifestada luego de la Conquista a Santa Catalina de Alejandría, mártir protectora de los tejedores ${ }^{2}$. Los indígenas se fueron integrando a la religión católica y con ella llegó el fervor por los santos patrones afines a sus oficios. San Eloy, santa Bárbara, San Crispín, san Crispiniano... o san Lucas -santo de los pintores-, en el siglo XVII ya ocupaban el lugar de las deidades ancestrales ${ }^{3}$. Sin embargo, no fue un hecho automático, desde el choque de ver la destrucción violenta de los "tunjos" a los indios que por voluntad se integraban a cofradías religiosas y donaban imaginería católica transcurrieron como mínimo un par de generaciones ${ }^{4}$.

Las visitas a santuarios de Boyacá hechas con el ánimo de extirpar idolatrías dejarían registro de objetos utilizados en los cultos indígenas. Los inventarios levantados por los españoles denominaron a estas imágenes de acuerdo a su saber y entender. Así, aparecen en los documentos palabras como "santillos", "ídolos" y "hechurillas". Las figuras de algodón y de palo fueron a parar a la hoguera, mientras que las de oro y esmeraldas fueron conservadas para aprovechar estos materiales preciosos ${ }^{5}$. Pero la extirpación no se limitaba a la quema pública y ejemplar de templos e ídolos, ésta se acompañaba de reprimendas físicas que hicieron que estas primeras generaciones que se acercaban a la cristiandad buscaran formas de ocultar sus prácticas, llevando los "tunjos" a sus casas o escondiéndolos entre los cultivos de maíz 6 .

Estas irreversibles y agresivas destrucciones de ídolos hacen parte de lo que Serge Gruzinski ha calificado como "guerra de imágenes". La eliminación de imágenes incompatibles con la religión católica no solamente fue una medida necesaria para introducir a los indios en el cristianismo sino que también desestabilizaba en todo sentido a la población, ya diezmada por las luchas y epidemias ${ }^{7}$.

Desaparecer todo vínculo tangible del indígena con su religión era apenas uno de los primeros pasos para que se convirtiera al cristianismo. La misión doctrinal hacia las poblaciones que por primera vez escuchaban el evangelio era complicada y sus estrategias debían adaptarse a un mensaje teológico pero también a las características de cada grupo, a

\footnotetext{
${ }^{1}$ López, 2001: 53. para la Corona. en 1585. En: Corradine, 2009: 92, 93. que ahora deberían hacer y venerar? Ver: Russo, 2014: 5.

${ }^{5}$ Ver inventarios de las visitas a santuarios de Boyacá en: Cortés (1960): 199 - 273.

${ }^{6}$ Langebaek, 2005: 25 - 51.

${ }^{7}$ Gruzinski, 1994: 71 y 71.
}

2 La pintura mural del presbiterio de la Iglesia de Nuestra Señora del Rosario de Turmequé, datada entre 1587 y 1611, presenta una imagen de Santa Catalina de Alejandría. Este era el pueblo que más mantas producía

3 Ver por ejemplo la participación de indios con pendones en las procesiones de Corpus Christi en Tunja,

${ }^{4}$ Acertadamente, en el caso novohispano, Alessandra Russo se ha planteado la pregunta que debieron hacerse muchos indígenas: ¿cómo podía ser el shock de la conquista un modelo del que surgieran las imágenes 
sus respuestas, a la disponibilidad de instrumentos humanos y materiales para llevar a cabo esta tarea, entre muchas otras variables ${ }^{8}$.

\section{Al abrigo de las mantas}

Las mantas fueron objetos de gran valor simbólico, de uso y económico, tanto en periodos prehispánicos como en los siglos posteriores a la Conquista. Fray Pedro Simón, a principios del siglo XVI, las consideró una de las "riquezas" de los indios junto al oro, la plata, las esmeraldas y las perlas ${ }^{9}$. Según este cronista, los indios le contaban que el dios de los tejedores de mantas era Nencatacoa que además era dios de las borracheras, quien se aparecía en la figura de un oso o de zorra cubierto por una manta y que le gustaba beber chicha (una bebida de maíz fermentado ${ }^{10}$. Pero según el mismo autor, los muiscas atribuían la enseñanza del hilado de algodón y el tejido de mantas a Bochica, Nemterequeteba, Xué o Sugunsua -el nombre y la historia variaban un poco según el lugar ${ }^{11}$ - porque antes de su llegada vestían con planchas de algodón atadas con fique, y para que no lo olvidaran, el dios dejaba dibujos de los telares en piedras de los pueblos por donde pasaba. La geometría que tenían algunas mantas fueron asumidas por fray Pedro Simón como representaciones de la cruz de Cristo y supuso que las personas identificadas como deidades entre los muiscas los habían instruido -antes de la llegada de los españoles- en los misterios, la encarnación y la muerte de Cristo y por ende aparecían diseños con cruces en sus textiles ${ }^{12}$.

La presencia de las mantas en la cultura muisca se remonta a los mitos de los orígenes de este pueblo. Se contaba que el Gran Chacha, hijo del Sol, caminaba sobre mantas puestas en el suelo para que no tocara el suelo en el camino que iba desde su palacio al templo del sol construido en Tunja. En los entierros funerarios, las mantas eran utilizadas para envolver ofrendas o a los muertos mismos; al parecer en épocas prehispánicas estas prácticas se hacían dentro de espacios domésticos, y luego de la llegada de los españoles se llevaban a cabo en lugares aislados para ocultar estas actividades fuertemente reprendidas. Si el fallecido era alguien notable la manta que lo envolvía era pintada ${ }^{13}$.

La manta como vestuario adquirió significados especiales, por ejemplo, el psihipqua ${ }^{14}$ de Sogamoso, de quien se decía era el heredero de Bochica, el dios que les había enseñado a hilar y a tejer mantas en esta población, usaba una manta blanca para dar a entender que su ira había dañado sus cultivos de maíz quemándolos con heladas. Untar bija sobre la manta era un honor propio del psihipqua y era el único que podía vestir mantas pintadas y joyas de oro pues los demás debían pedirle permiso para poder hacerlo; por este valor simbólico de poder, este tipo de mantas decoradas fueron regalo del psihipqua a los jefes locales. Según las declaraciones hechas por los muiscas a los visitadores, antes de la llegada de los españoles a sus territorios las mantas eran un objeto muy apreciado que se daba a los psihipquas junto a oro y esmeraldas, como símbolo de sujeción, lo que se siguió haciendo un tiempo después de la conquista. Con la llegada de los españoles muchas cosas cambiaron y los psihipquas ya no podían ser llevados en andas como lo solían hacer en épocas prehispánicas, ahora eran

${ }^{8}$ Los ciclos de evangelización temprana en América pueden diferenciarse según sus etapas en: kerigma, catequética y homilética. Para una explicación de cada una de ellas, ver: Valenzuela, 2015: 13 -32.

${ }^{9}$ Simón, 1892: 44.

10 Simón, 1981: T. III, 378.

${ }^{11}$ Los nombres de estos dioses son muestra de la heterogeneidad de los distintos pueblos que habitaron el altiplano Cundiboyacense y que se han denominado "muiscas". En los últimos años se ha planteado una discusión en torno a la imprecisión de esta generalización. Ver: Gamboa (2016): pp. 11 -33.

12 Simón, 1981: T. III, 374 - 376. Correa, 2004: 34 - 38, 348, 356, 374.

Ver imágenes de pintura rupestre que se han identificado como "piedras de los tejidos" en:

Martínez Celis, Diego (s/f): "Arte rupestre, tradición textil y sincretismo en Sutatausa (Cundinamarca)". En: http://www.rupestreweb.info/sutatextil.html [1 de junio de 2016].

13 Gamboa, 2013: 93, 94, 491.

${ }^{14}$ Denominación de los jefes muiscas en esta lengua. Ver: Gamboa, 2013: 13, 48. 


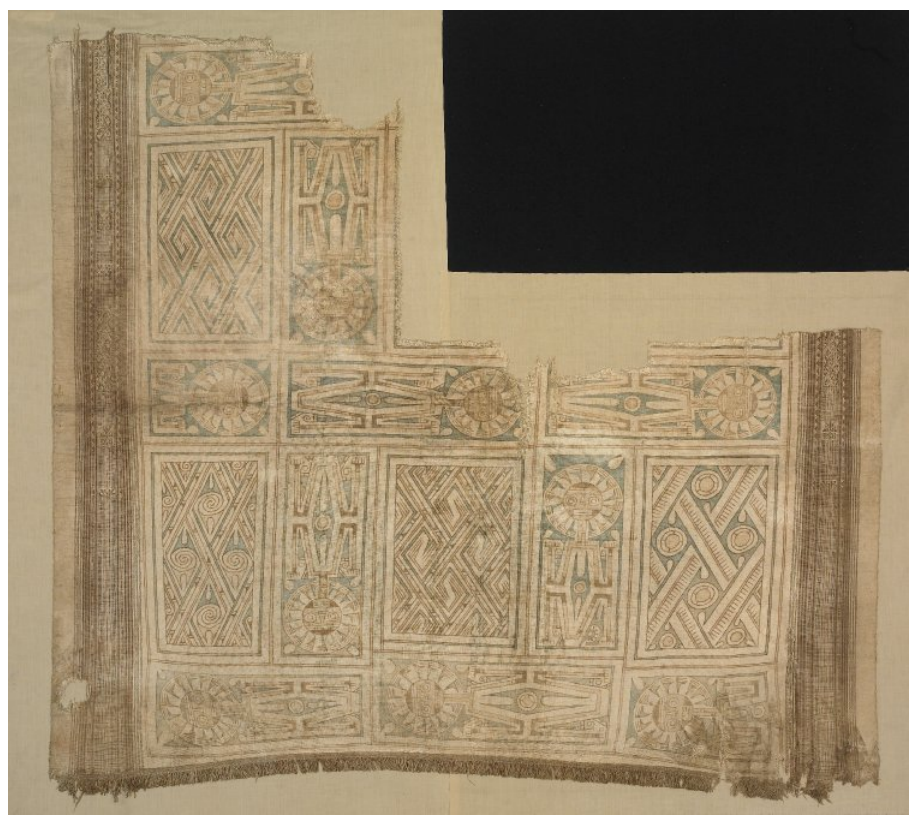

Fig.1. Manta muisca. Tejido de algodón pintada con pincel. 122 x $135 \mathrm{~cm}$ Siglo XIV-XV d.C. Colección British Museum Número de registro Am1842,1112.3 (C) The Trustees of the British Museum.

ellos los que pagaban una multa de 50 mantas por infringir esta prohibición. De otro lado, una manta rasgada y el cabello cortado eran signos de que la persona que la usaba había cometido una falta o un delito menor, esto inicialmente era un castigo llevado a cabo por los muiscas pero luego también fue implantado por los encomenderos y los curas doctrineros ${ }^{15}$. Como vestimenta, las mantas eran usadas por los indios pues al parecer los mestizos y españoles debían usar "ropas de Castilla" ", aunque tenían muchos otros usos como cobijas, telas para uso doméstico y seguramente para el abrigo personal en los espacios privados.

Cronistas como fray Pedro de Aguado y Juan de Castellanos afirmaron que a los primeros españoles que llegaron a tierras muiscas se les ofrecieron mantas, oro y esmeraldas como regalo. Al principio no las consideraron valiosas pero luego se dieron cuenta de que eran un bien muy estimado por los indígenas y podían tener gran importancia como objeto de trueque; tanto así que más tarde los indios se quejaron de torturas por parte de españoles que les exigían oro y mantas. Pronto los españoles comprenderían que una manta fina era una buena forma de acercarse a un cacique y mejorar las relaciones entre ellos.

Estos tejidos se usaron como compensación: en el caso de un delito grave como un homicidio hubo pago de multas a través de mantas. También fueron bienes que sirvieron para que el marido de una mujer muerta en el parto indemnizara a los familiares de su esposa por la pérdida. La solicitud de justicia al psihipqua se hacía llevándole mantas u oro, y también estos textiles fueron premios en carreras deportivas.

La ceremonia en la cual un psihipqua se convertía en vasallo de la Corona y aceptaba la implantación de la encomienda en su territorio tenía un ritual con la manta que era muy significativo: el encomendero le quitaba y le volvía a poner esta vestimenta, mientras el escribano apuntaba que todo se había hecho sin oposición alguna, entonces el muisca entraba en la categoría jurídica y social de indio. Por otro lado, la entrega de una manta colorada y un bonete por parte de un psihipqua a los herederos de cacicazgo de sus territorios daba a conocer públicamente la aceptación de estos cargos.

Como bien de cambio y venta las mantas ocuparon un papel fundamental, sirvieron de mercancía-moneda y fue común este uso en territorios de lo que hoy es Cundinamarca y Boyacá. Como ejemplo se puede citar el compromiso de Jerónimo Gutiérrez, vecino de La

${ }^{15}$ La constatación de estos usos y significados de las mantas se puede encontrar en crónicas y documentos ampliamente estudiados en: Gamboa, 2013.

16 Gamboa, 2013: 466. 
Palma (Cundinamarca) y residente en Tunja, de pagar al mercader Diego Díez 475 pesos y 4 tomines de oro de 20 quilates a través de ropa (mantas) hechas en La Palma, pueblo productor de algodón y en donde funcionaba un obraje de tejidos. Este "trueque" se realizó por los siguientes bienes: 8 manos de papel a 10 tomines la mano (10 pesos), dos docenas y media de papeles medianos de figuras, a dos tomines y medio cada uno" ( 9 pesos y 3 tomines), cinco rosarios (6 pesos), tres rosarios de ébano ( 2 pesos y medio) y seis "papeles grandes" $(10 \text { pesos })^{17}$.

Los muiscas pagaban parte de su tributo en mantas blancas, coloradas o pintadas, y pidieron que parte del oro y la plata que debían dar se reemplazara por estas telas de algodón porque era más fácil para ellos; esta petición se aceptó y así circularon sobre todo en la segunda mitad del siglo XVI. Con el tiempo, fue beneficioso para los encomenderos ya que así evadían el quinto real, y a su vez, ellos mismos también podían pagar el trabajo a los indios en mantas. En Santafé, a mediados del siglo XVI, un indio tributario debía dar anualmente una manta de la marca, dos tomines de oro y media fanega de maíz (27,75 litros). Según la encomienda, el precio de una manta cambiaba, hubo lugares en los que se pagó un peso por 2 o 3 mantas pero hubo otros que por el mismo precio se daban 6 mantas. En 1560, el precio de una manta se fijó en 5 tomines de oro corriente ${ }^{18}$.

Para tener una idea del valor que podían tener, se han establecido algunas equivalencias: en 1560, una carga de algodón podía intercambiarse por una cantidad de "mantas buenas" que iba de 4 a 8 unidades; una manta blanca buena podía valer lo mismo que una fanega de maíz o de fríjol; un bohío valía tres o cuatro mantas finas; y en cuanto a una "manta chinga"19 podría cambiarse por una carga de papas o por cuatro totumas de frijoles ${ }^{20}$.

Las crónicas y las quejas que denunciaban robos de mantas indígenas por parte de los españoles causaron la emisión en 1530 de una cédula real en la cual la reina Isabel ordenaba que no se permitieran tales abusos contra los indios ${ }^{21}$. Estaba prohibido quitarle a los indios sus mantas, siendo tan grave hacerlo que fray Pedro Simón registró la ejecución de un soldado español ordenada por Gonzalo Jiménez de Quesada, fundador de Santafé de Bogotá.

Las mantas fueron objetos que pasaron a otras manos por medio de las herencias y también se comercializaron en tiendas. En Tunja, en 1593, el mercader de Anserma, Alonso Martín le compró mercancías a Félix del Castillo por pesos de oro corriente, es decir de 13 quilates. Entre los objetos se inventariaron seis mantas de pincel en 7 pesos y medio de 20 quilates que pagó en un equivalente de 11 pesos y 4 tomines de oro corriente, dos mantas de lana en 2 pesos de oro corriente, una manta blanca de algodón en 1 peso y 1 tomín de oro corriente y seis frazadas a 4 pesos cada una ${ }^{22}$. Estos datos nos hacen pensar en la presencia extendida que tuvieron estos tejidos por otras provincias del Nuevo Reino de Granada.

En 1594, el oidor Ibarra realizó investigaciones sobre la doctrina de los repartimientos de Suta y Tausa encomendados en Gonzalo de León Venero. Actuando como testigo don Diego Tenasuchiguya, capitán de Tausa, afirmó que un padre dictó penas a los indios por estar amancebados, y que ellos pagaron la multa en mantas y oro para comprar una caja para

17 Obligación de Jerónimo Gutiérrę, 1591, Archivo Histórico Regional de Boyacá, Tunja (AHRB), Notaría segunda, t. 45, ff. 349v-352r.

18 Gamboa, 2013: 309, 407, 412, 414.

${ }^{19}$ Una manta chinga era una manta burda. Ver: Gamboa, 2013: 97.

20 Gamboa, 2013: 394, 395. f.32.

${ }^{21}$ Real cédula, 1530, Archivo General de Indias, Sevilla (AGI), SANTA_FE, 1174, L.1, Madrid 1530 - 4-5,

Real Cédula de $\mathrm{D}^{\mathrm{a}}$ Isabel al gobernador y capitán general de la Provincia de Sta. Marta, para que no consienta que ninguna persona robe a los indios, ni les tomen mantas, plumajes y atavíos de sus casas, ni hagan daño a sus personas y haciendas, ni reciban de ellos mas de lo que de su voluntad les quisieren dar, proveyendo en todo de manera que se guarden las Instrucciones que están dadas acerca de su buen tratamiento y conversión.

22 Obligación de Alonso Martín, 1593, AHRB, Notaría Segunda, t. 51, ff. 122v-124v. 


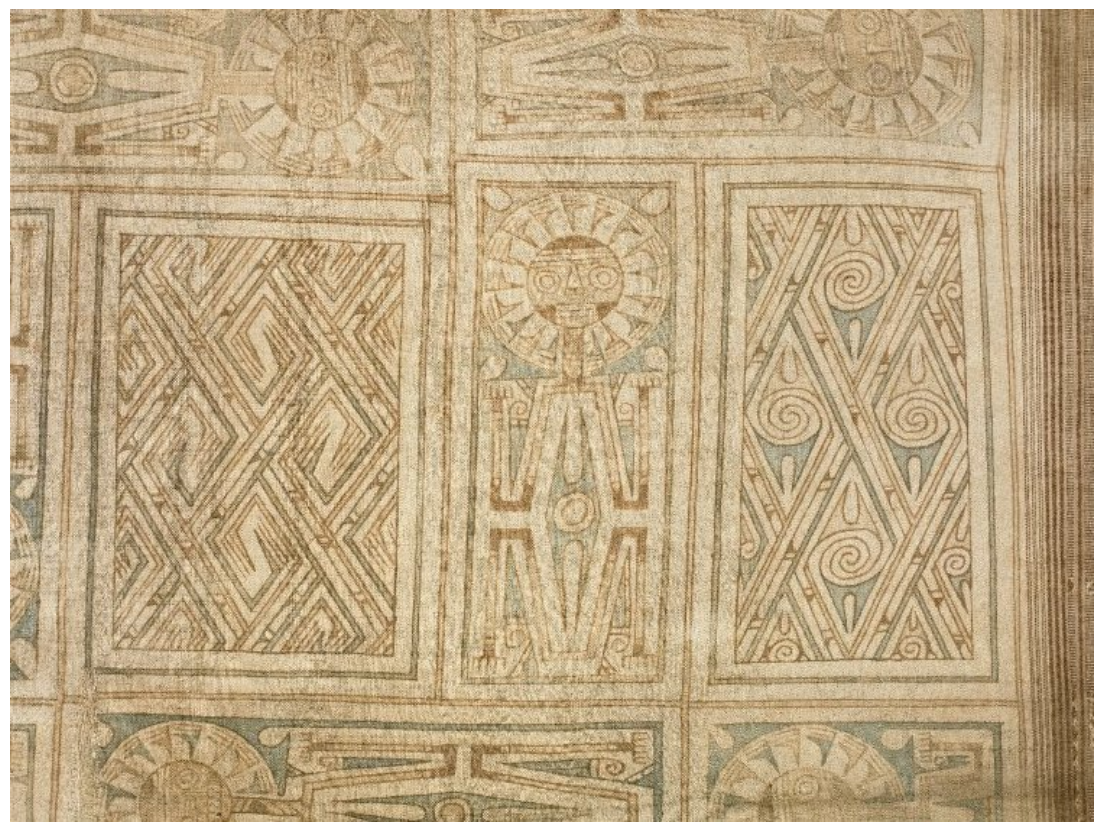

Fig. 2. Por menor manta Am1842,1112.3. Colección

British Museum (C) The Trustees of the British Museum.

guardar los ornamentos que costó 6 pesos, y afirmó que la iglesia tenía además 10 mantas ${ }^{23}$. Como se observa, la circulación de las mantas se amplió y se multiplicó al ser aceptadas como mercancía moneda.

Gracias al trueque entre grupos indígenas, a las imposiciones tributarias y laborales de los españoles a los indios y a la necesidad de tener templos mínimamente dignos para la liturgia, las mantas llegaron a iglesias de otros territorios neogranadinos. El templo de San Juan de La Vega, que aunque no fue pueblo muisca sino panche, sí tuvo en 1604 entre sus bienes una manta colorada y de pincel, además de un Cristo de bulto pequeño con la cruz de ébano, una imagen de lienzo, pequeña y sin marco de Nuestra Señora del Pópulo y una imagen de bulto dorada de Nuestra Señora de la Concepción ${ }^{24}$.

$\mathrm{El}$ inmenso valor a todo nivel que los pueblos muiscas otorgaban a estas telas debe estar presente a la hora de imaginar a estas primeras generaciones de indios que se adentraban en el orden social hispánico y veían los nuevos roles de sus textiles.

\section{Cielos de algodón}

La compleja transición del indio gentil a indio cristiano necesitó de una operación de 'aniquilación y sustitución ${ }^{25}$. Los tunjos fueron cambiados por la imaginería católica, y las mantas variaron sus temas pictóricos y usos. Los indígenas debieron acostumbrarse a ver sus tejidos cubriendo altares de iglesias pero no sabemos si esta ornamentación sirvió para adentrar a los indios más adelantados en la doctrina en el estudio del libro del Éxodo para entender sus orígenes o si por el contrario ante la prioridad de otros temas en la doctrina pasó ante sus ojos como una mera decoración.

23 Suta y Tausa: investigaciones en repartimientos indigenas, 1594, Archivo General de la Nación, Bogotá (AGN), Colonia, Visitas de Boyacá, t. 17, año 1594, f. 315r.

${ }^{24}$ Visita a San Juan de La Vega, 1604, AGN, Colonia, Visitas Cundinamarca, t. 1, año 1604, f. 567v.

25 Gruzinski, 1994: 41. 
Se denominaba cielo a la cobertura textil ubicada en la parte superior del altar y que tenían varias funciones: protección, ornamentación y focalización de la mirada ${ }^{26}$ pero también simbólica. El uso de cielos de tela fue una constante en las iglesias de doctrina, a modo de baldaquino, costumbre que aún a mediados del siglo XVII se seguía manteniendo, un poco atrasada con respecto a lo que sucedía en España ${ }^{29}$.

Los textiles en los altares remiten al santuario, al atrio y a la tienda que Dios ordenó hacer a Moisés, los cuales son descritos ampliamente en la Biblia en cuanto a su material, color, decoraciones, medida, ubicación y forma de montaje. Entre las indicaciones dadas por El Señor se tienen las siguientes: "Haz el santuario con diez cortinas de lino torcido, tela morada, tela de púrpura y tela roja; borda en ellas artísticamente dos seres alados" (Exodo 26, 1), igualmente, le hizo mención al velo de telas de lino, bordadas con un par de querubines que debía cubrir el Arca de la alianza (Éxodo 26, 31 - 35), así como las cortinas de lino que mandaba colgar en el atrio (Éxodo 27, 9-19).

Ante las exigencias y las revisiones que se hacían a la arquitectura y a las dotaciones de las iglesias en los pueblos, los indios debieron intuir la materialidad preciosa que debían tener los lugares sagrados ${ }^{28}$ : Y ahí estaban sus mantas -cielos protectores y testigos de ceremonias litúrgicas-. Por un lado, las mantas atendían la demanda de textiles que se demoraban en llegar a los pueblos porque dependía de los ritmos dictados por la flota que llegaba a Cartagena de Indias y del tiempo que tardaban los comerciantes en adentrarse al Reino por el río Magdalena y la cordillera de más de 2600 metros de altura; por el otro, existía una continuidad en la dedicación a un oficio prehispánico que suponía para los encomenderos, corregidores y doctrineros una tarea menos de enseñanza e implantación, ese conocimiento ya manejado por los indígenas era una ventaja para los españoles.

Los registros de las visitas hechas a finales del siglo XVI y en las primeras décadas del XVII a iglesias de doctrina de indios del altiplano cundiboyacense colombiano revelan la presencia frecuente de mantas en estos espacios eclesiales de los pueblos muiscas, especialmente alrededor del altar. Es posible que las menciones hagan referencia tanto a mantas pintadas con temas católicos como a mantas al pincel con diseños muiscas de tipo geométrico o teñidas de un solo color como las coloradas. Esta hipótesis se plantea por el hecho de que en repetidas ocasiones los inventarios solamente nombran la presencia de "mantas", mientras que en el resto de referencias a estas telas se especifica el tema de la pintura. Es fundamental señalar que partir de las visitas en la Provincia de Tunja, la Real Audiencia ordenó en 1575 que se prohibieran las mantas pintadas en las iglesias porque podía ser que fomentaran las idolatrías entre los indígenas, ya que en ellas los españoles veían las figuras de tunjos y demonios ${ }^{29}$. (fig. 1 y 2) Cabe preguntarse si las mantas con pinturas geométricas - sin tunjos- tenían significados legibles para los muiscas (tal como sucedía con los tocapus incas), pasando desapercibidos para los españoles que con la eliminación del temido motivo prehispánico veían suprimido cualquier atisbo de remembranza a sus deidades.

El uso de mantas dentro de los espacios eclesiales debió ser algo asimilado, aceptado y hasta alentado por los españoles, quienes en las mismas trazas de templos ya proyectaban su presencia, obviamente cuidando que no aparecieran "ídolos" pintados. Ejemplo de ello es la traza general del templo de Guaramito, de 1602, en la que no solamente se daban indicaciones de los diseños, dimensiones y materiales constructivos sino también la precisión de hacer un altar de adobe o tapia y encima de él una imagen de pincel y un cielo y frontal de lienzo o manta. De la misma manera el visitador Andrés Egas de Guzmán informó en 1594 de la inexistencia de una iglesia donde dar doctrina a los indios de Bombaza, por lo que dio instrucciones de lo que se debía hacer, dejando por escrito su mandato de dotar el interior

\footnotetext{
${ }^{26}$ Abellán, 2002: 31.

${ }^{27}$ Herrera / Gila (2013): 308.

${ }^{28}$ Chica, 2016: $26-31$.

${ }^{29}$ Gamboa, 2013: 493.
} 


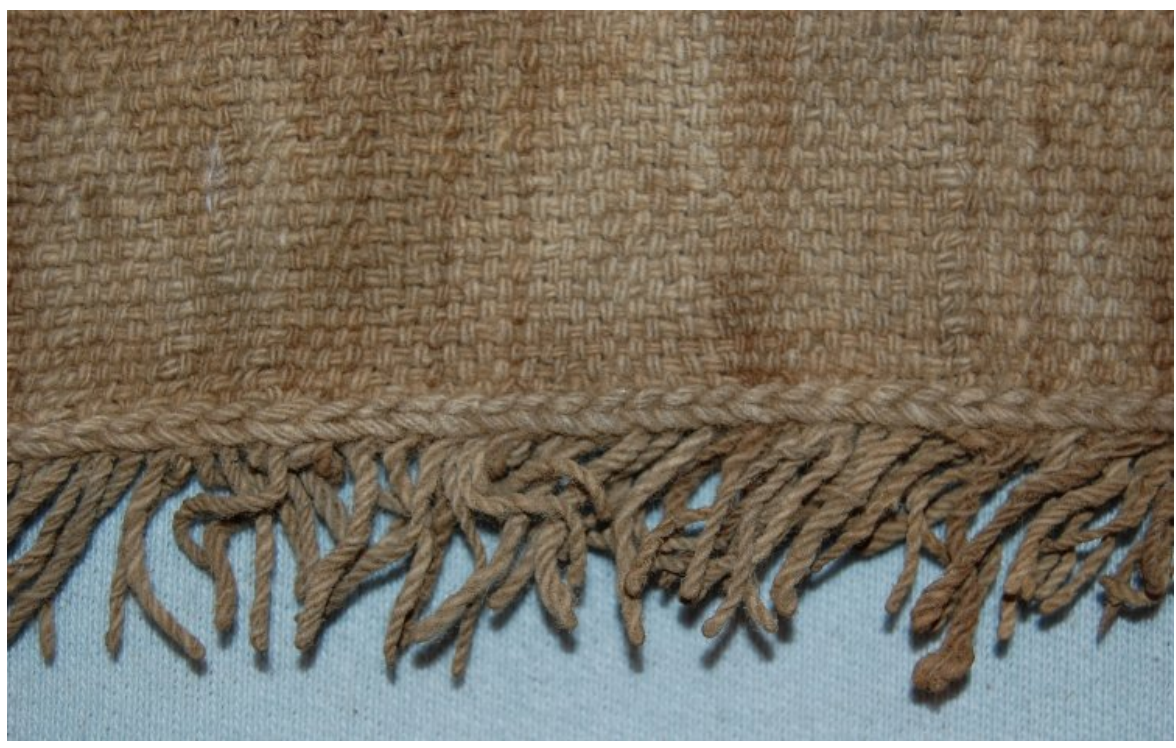

Fig. 3. Por menor Manta muisca Tejido de algodón con hilos teñidos 92 × 26 cm 1300 - 1400 d.C. Colección British Museum. Número de registro Am1842,1112.4 (C) The Trustees of the British Museum

con una manta para debajo de los manteles del altar, dos mantas pintadas para los lados del altar y un cielo de mantas pintadas, entre los demás ornamentos e imágenes básicos ${ }^{30}$.

La relación de mantas que se presenta a continuación muestra las iconografías que en ellas se plasmaban y otras imágenes que las acompañaban, dato que puede ser importante a la hora de realizar lecturas de estos espacios en cuanto a su uso didáctico y devocional; por ahora se destaca el tema cristológico, especialmente la Pasión. En 1592, el visitador Bernardino de Albornoz fue a la iglesia de Suta, una construcción de tapias y cubierta de paja, y entre sus bienes encontró doce mantas pintadas de diferente color alrededor del altar, y en el cielo, cuatro mantas y en ellas pintada la Pasión, un lienzo de la Magdalena, un lienzo con un crucifijo en él y San Juan, María Santísima y la Magdalena ${ }^{31}$.

El oidor de la Real Audiencia, Miguel de Ibarra, en julio de 1593, visitó la iglesia de Chocontá, en cuyo inventario se registró un cielo de manta encima del altar, con una guarnición de madera y otras tres pintadas en el altar, en la pared y en el cielo, andas, y una manta para enterrar a los muertos ${ }^{32}$, uso que no era extraño para los muiscas que tenían esta práctica, así como la de envolver las momias con finas mantas ${ }^{33}$. En 1594, el escribano Sancho de Camargo fue a la iglesia de Suta y realizó la visita en presencia del padre Pedro de Aguirre, al parecer aún estaban las mismas mantas con la escena de la Pasión de Cristo y el cielo de la visita de 1592, y se tomó la siguiente nota: "Se vido el altar mayor que tenía cuatro mantas pintadas de la historia de la Pasión, que sirven de ornato del altar las tres que tienen la dicha historia y la otra de cielo del altar... [y] dos mantas pintadas y una líquida que sirven de guarda frontal y están puestas debajo del frontal' ${ }^{34}$, además de un Cristo pequeño que estaba en el altar y un lienzo de la Magdalena guarnecido de madera, este último ya visto dos años atrás. La revisión de 1600 realizada en Fómeque dejó constancia de mantas junto a imágenes

\footnotetext{
${ }^{30}$ Romero, 2008: 729, 730, 874, 875.

31 Visita a Suta, 1592, AGN, Colonia, Encomiendas, t. 3, ff. 446r - 447v.

32 Visita a Chocontá, 1593, AGN, Colonia, Visitas de Cundinamarca, t.11, ff. 214 v.-216 v.

33 Gamboa, 2013: 134.

34 Visita a Suta, 1594, AGN, Colonia, Visitas de Boyacá, t. 17, f. 333rv.
} 
católicas: tres mantas "despintadas" y una blanca, todas para el adorno del altar, cuatro mantas pintadas (tres viejas y una nueva), un lienzo de un Ecce Homo, un lienzo viejo de Nuestra Señora de los Ángeles, un frontal de guadamecí con una imagen de Nuestra Señora, dos lienzos pequeños cada uno con una pintura de un crucifijo y dos retablos de Nuestra Señora $^{35}$. La iglesia de Tenjo, en 1603 contaba con una manta grande pintada que servía de cielo del altar y doce mantas pintadas (sin notas sobre sus temáticas o diseños), un lienzo sin marco de Cristo crucificado acompañado de Nuestra Señora de las Angustias y san Juan y otro lienzo de "figuras"36. En este punto, se debe recalcar que estas revisiones eran hechas por funcionarios de la Corona, lo relacionado con las imágenes y ornamentos religiosos no era tarea exclusiva de religiosos.

Durante 1602, el oídor Luis Henríquez visitó Soatá encontrando "varias mantas pintadas para adornar el altar", y en el templo de doctrina de Busbanzá halló dos mantas coloradas que servían de cielo de altar y otras dos, también coloradas, a los lados del altar, acompañadas de estampas, guadamecíes, un retablo, reposteros e imágenes de bulto. Continuando con las visitas de ese año, Henríquez fue a Ceniza y en su iglesia encontró diez mantas de pincel coloradas y negras que adornaban el altar, cinco mantas de pincel con las que estaba hecho un cielo para el altar, un frontal negro de manta y un frontal de manta pintada. La iglesia de doctrina de Iza tenía entre sus bienes dos medias mantas blancas, dos mantas de pincel, cinco mantas blancas, dos de ellas en el altar, y una manta colorada, a las que se sumaban pinturas religiosas sobre lienzos e imágenes de bulto. En Paipa, hubo un gran adorno del cielo y del altar conformado por catorce mantas coloradas y blancas acuchilladas, y en el caso de la doctrina de los indios de Támara tenían una ornamentación textil que se consideró como "un cielo de manta de pincel bueno", según el inventario de 1602. En otros listados se especificaron las imágenes pintadas, como el Cristo pintado en una manta que tenía la iglesia de Tabio en 1638. Algunos inventarios dan la idea de conjuntos formados por las pinturas y las mantas, es el caso de Tenjo, cuyo templo en 1638 tenía "un lienzo con la hechura de un Cristo con Nuestra Señora de las Angustias y san Juan... Otro lienzo por guarnecer de figuras... Una manta grande pintada que sirve de cielo del altar. Doce mantas pintadas que están a los lados del lienzo del dicho" ${ }^{37}$.

Además de cielos, las mantas sirvieron de frontales y vestimentas litúrgicas. En 1596, la visita de Egas de Guzmán al pueblo de Pesca registró una manta pintada que servía de frontal, una manta para debajo de los manteles de altar, dos mantas pintadas para los lados del altar, una cruz de madera dorada con su manga pintada con flocadura y, nuevamente, un cielo de mantas pintadas para el altar. En 1601, la misma población registraba un cielo de manta pero con caídas de tafetán de colores y con borlas, quizás era el mismo pero la descripción fue más precisa. En 1600, el oídor Luis Henríquez inventarió dieciocho mantas pintadas que servían de dalmáticas para los jóvenes cantores de Cáqueza ${ }^{38}$; años atrás, la visita de 1594 , en esta misma población, comprobó la existencia de una manta blanca que era usada como cielo del altar mayor, más cuatro guadamecíes viejos que servían de ornato del altar, una imagen de Cristo en un lienzo sin marco, un retablo pequeño del descendimiento de Cristo de la cruz, un retablo de madera con un lienzo con la escena del prendimiento de Jesús y un lienzo de la pasión de Cristo ${ }^{39}$. Entrado ya el siglo XVII, las mantas se siguen adaptando como partes de objetos litúrgicos; el inventario de la iglesia de Cocuy y Panqueba, de 1635, da noticia de otro frontal formado por telas de diferente procedencia, por un lado un terciopelo de China de color verde ${ }^{40}$, fondo en raso de seda, flecos de seda azul, aforrados por una

\footnotetext{
35 Visita a Fómeque, 1600, AGN, Colonia, Visitas Cundinamarca, t. 4, ff. 291v - 292r.

36 Visita a Tenjo, 1603, AGN, Colonia, Visitas Cundinamarca, t. 6, ff. 14rv.

${ }^{37}$ Romero, 2008: 450, 1811, 1942, 2371, 2513, 3333, 2824, 2830, 729, 730, 874, 875.

38 Romero, 2008: 251, 2567, 241.

39 Visita a Cáqueza, 1594, AGN, Colonia, Visitas Cundinamarca, t. 2, ff. 926v - 927r.

40 Para el tema de objetos asiáticos en pueblos de indios cundiboyacenses, ver: Romero / Ruíz, 2010: 111 -
} 130. 
manta negra, ornamento donado por los caciques de estas dos poblaciones ${ }^{41}$; este ornamento podría ser ejemplo perfecto de la "mundialización ibérica"42 que se inició con la expansión de la monarquía española: asiático por un lado, muisca por el otro, parte del ceremonial católico y costeado por indios. El lector podrá denominar un hecho así como "sincretismo", "hibridación", "transculturación", "semiosis colonial", palimpsesto", entre otros términos, ante la imposibilidad de llegar a un acuerdo definitivo de designación de los fenómenos materiales y conceptuales ocurridos en las creaciones artísticas americanas posteriores a la conquista $^{43}$. Igual reflexión nos causa el pensar que hacia 1594, en Cucunubá, el padre del templo vestía una casulla de manta.

Los testamentos también dieron cuenta de la presencia de mantas en espacios civiles. Es el caso de Diego Vales, vecino de Tunja, quien testó en 1593, enumerando entre sus bienes: una imagen de Nuestra Señora Santa Ana guarnecida en plata, tres lienzos: uno de la Oración del huerto, otro un crucifijo con San Juan y Nuestra Señora y otro un descendimiento de la cruz, un lienzo del señor San Francisco, una imagen de Nuestra Señora del Rosario en tabla, dos "papeles de Flandes", seguramente haciendo referencia a unas estampas, una de Nuestra Señora del Rosario y otra de los seis Doctores de la Iglesia, tres bastidores con sus dos bancos, uno grande y otro pequeño y tres mantas de pincel $^{44}$.

Entre los bienes de dotes se incluyeron mantas, apreciadas por la versatilidad de sus usos, fueron fundamentales en la protección del frío en esta región montañosa de los Andes. En 1593, en Tunja, Melchor de los Reyes, barbero, dio a su mujer Margarita de Vales un recibo por un valor total en bienes de 1.400 pesos de oro corriente de 13 quilates, entre lo que se contó: La hechura de un lienzo en bastidor de Nuestro Señor Jesucristo, Nuestra Señora, San Juan y la Magdalena y otros lienzos de la Oración (en el huerto) y el Descendimiento (de Jesucristo), apreciados los tres en 60 pesos de oro corriente, un lienzo del señor San Francisco valorado en 7 pesos de oro corriente, dos "papeles de pinturas" grandes avaluados en 2 pesos, tres papeles de la Resurrección y de la Muerte (de Jesús) y un Cristo a un precio de 1 peso y medio, y una manta pequeña de pincel que valía un peso ${ }^{45}$. Al no darse el tema de la pintura de pincel sobre manta, se podría suponer que se trata de las geometrías usuales en los diseños muiscas o de mantas monocromas.

Observando estas obligaciones de pago, testamentos, dotes y ventas, podríamos plantear un "mestizaje" en sentido inverso, el de grupos sociales -diferentes a los indios- que tienen mantas en sus casas, apropian este producto "de la tierra" y lo acomodan a sus necesidades.

\section{Vírgenes sobre algodón}

Es común que en los inventarios de obra colonial en Colombia no se detalle la materia prima del soporte, se registra genéricamente como "tela" o "lienzo". Para establecer la frecuencia de uso de algodón sería necesario verificar en el laboratorio el tipo de fibra en las pinturas conservadas en los que fueron pueblos de indios en Cundinamarca y Boyacá. Sin embargo, gracias a los trabajos de restauración se puede asegurar la presencia de algodón en dos imágenes marianas consideradas milagrosas y de gran devoción.

La imagen de Nuestra Señora de Chiquinquirá es la pintura más conocida entre las que utilizaron mantas de algodón de elaboración indígena como soporte en el Nuevo Reino de Granada $^{46}$. Esta pintura debió ser pintada alrededor de 1555 y $1562^{47}$, ha sido atribuida al

${ }^{41}$ Romero, 2008: 1215, 2032.

42 Gruzinski, 2006: 217 - 237.

43 Russo, 2014: 4.

${ }_{44}$ Testamento de Diego V ales, 1593, AHRB, Notaría Segunda, t. 50, ff. 219r-223r.

45 Dote de Margarita de V ales a Melchor de los Reyes, 1593, AHRB, Notaría Segunda, t. 50, ff. 287v-292v.

46 Una de las mejores fotografías de la pintura de la Virgen de Chiquinquirá se puede observar en: "Cofradía de Nuestra Señora del Rosario de Chiquinquirá" (s/f). En: http://virgendechiquinquira.org/wpcontent/uploads/2015/08/Cofradia-Virgen-de-Chiquinquira.jpg [17 de mayo de 2016].

${ }^{47}$ Romero, 2011: 13. Acosta, 2009: s/p 
andaluz Alonso de Narváez y es famosa por su milagrosa renovación ocurrida en 1586. Su renovación fue tratada por varios autores, como fray Pedro Tobar y Buendía quien especificó que la pintura fue hecha "en una manta de algodón que era el lienço, que avía en aquel

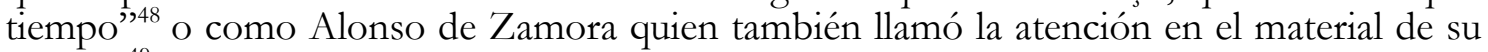
soporte $^{49}$. En 1674, Juan Flórez de Ocáriz en el Libro primero de las genealogías del Nuevo Reino de Granada hizo mención a una manta como soporte de la imagen mariana ${ }^{50}$.

Tom Cummins ha planteado que el tipo de manta de la imagen chiquinquireña guarda relación con la que viste la Cacica de Sutatausa en la pintura mural del templo de doctrina y resalta el énfasis puesto por Tobar y Buendía, Zamora y Flórez de Ocáriz en el material del soporte de la imagen milagrosa, cuyo origen indígena generaría sentimientos de identidad y orgullo al haberse manifestado la divinidad sobre un tejido de mano muisca; además, recuerda la relación establecida por Zamora entre la Virgen de Chiquinquirá y Rosa de Santa María (Santa Rosa de Lima) al interpretar los méritos de la limeña como primicia de la predicación en las Indias Occidentales, así como con la Virgen de Guadalupe mexicana pintada sobre una tilma de maguey ${ }^{51}$. En este sentido, Alessia Frassani relaciona a la cacica -por la forma triangular de su manto- con una Virgen tipo alcuza, alusión reforzada por su actitud orante con un rosario en sus manos y por su ubicación al lado de los murales del Viacrucis ${ }^{52}$.

La confirmación de que el soporte de la pintura de Nuestra Señora de Chiquinquirá es una tela de algodón la realizó la restauradora María Cecilia Álvarez en 1986:

"En cuanto a la manufactura de la tela, se ha comprobado, mediante el análisis microscópico de la fibra, que se trata de un tejido de algodón. La tela tiene una contextura muy delgada, de trama abierta, con un promedio de 14.5 hilos por centímetro cuadrado y tejida en telar manual. Lo más probable, sobre todo por lo delgado de las fibras y lo abierto de la trama, es que para darle un poco de rigidez al soporte, se haya encolado.

La obra no muestra la capa de base de preparación que habitualmente sirve de apoyo a la capa pictórica. El color se aplicó directamente sobre la tela impregnando los hilos.

Para la capa pictórica se utilizó blanco de España o carbonato de calcio, que era de muy fácil adquisición en su estado natural, mezclándolo con cola como aglutinante, a lo cual fueron añadidos colores de origen orgánico, obteniendo matices en escasa gama. Esta técnica explica el acabado general en tono mate que presentan las pinturas al temple." ${ }^{53}$

La obra actualmente presenta pérdida de capa pictórica generalizada, huellas de humedad, manchas de grasa y orificios producidos por elementos metálicos que perforaron la tela ${ }^{54}$.

El hincapié que el dominico Tobar hizo sobre el soporte de la Virgen de Chiquinquirá nos remite a lo que Gabriela Siracusano ha llamado "cuerpo" de la imagen, entendido como materia y sustancia, "portadores de cargas significantes al servicio de ciertas prácticas culturales y necesidades sociales, políticas o económicas" 55 .

La segunda imagen milagrosa con soporte de algodón tejido en telar manual es Nuestra Señora de las Angustias del pueblo de Labateca ${ }^{56}$; el material fue identificado en el proceso de

48 Tobar, 1694:12.

49 Zamora, 1701: 306.

${ }^{50}$ Acosta, 2009: s/p.

${ }^{51}$ Cummins, 1999: $67-74$.

52 Frassani, 2014: 82 - 84.

53 Sastoque Poveda, Luis Francisco, Fray O.P. (s/f): "Historia de Nuestra Señora del Rosario de Chiquinquirá" En: http://zeus.ustadistancia.edu.co/distancia/ventanainfinito/descargas/Libro\%20de $\% 20$ Chiquinquira.pdf

[17 de mayo de 2016]. Álvarez, 1986.

${ }^{54}$ Sastoque, s/f: 31.

55 Siracusano, 2009: 156.

56 Pese a su fama milagrosa, no es posible encontrar imágenes de alta calidad de la Virgen de Labateca; en internet se pueden ver algunas fotografías que no alcanzan la definición necesaria para ser publicadas. Ver: "Municipio de Labateca" (s/f). En:

http://municipiolabateca.jimdo.com/municipio-labateca/la-virgen-de-las-angustias/ [1 de junio de 2016]. 
restauración llevado a cabo por Hildegard Otto ${ }^{57}$. Esta pintura debió ser pintada alrededor de 1633, fecha de la fundación de la cofradía que lleva como nombre esta advocación de la Virgen y cuya historia tiene como protagonista a una india que lavaba en el río y a quien se le apareció el lienzo que posteriormente se renovó ${ }^{58}$.

Dada la ubicación del municipio de Labateca en el departamento de Norte de Santander, Colombia, surge la duda si el soporte de algodón no corresponde a una manta muisca sino guane, otro grupo indígena destacado también por sus tejidos hechos de los copos algodoneros. La tecnología de la elaboración de mantas en ambos grupos guardan muchas similitudes como la torsión de la fibra en $\mathrm{S}$ la mayor parte de las veces y en menor frecuencia en Z, el uso de las mismas especies vegetales para la obtención de pigmentos, los mismos mordientes, uso de telar vertical y decoración pintada. Como han señalado los estudiosos del tema es difícil diferenciar entre mantas guanes y mantas muiscas, siendo la zona de ubicación del entierro lo que sobre todo determina su clasificación, así como la comparación de los diseños pintados con diseños de cerámicas y esculturas de cada grupo ${ }^{59}$.

No se conoce la identidad del pintor de esta Virgen de las Angustias por lo que también cabe la posibilidad de que la pintura hubiera sido hecha en alguna región con mayoría de población muisca- donde hubo más presencia de pintores, especialmente en Tunja - y luego llevada a la población nortesantandereana. Sin embargo, no se debe olvidar la existencia de pintores en otras poblaciones como la de Vélez, departamento de Santander, en donde precisamente el pintor Simón de Lora llevó a cabo una obra para el templo mayor de dicha ciudad en 1606; el encargo se trataba de un óleo sobre lienzo de la Santísima Trinidad, Nuestra Señora y los doce apóstoles, para lo cual le darían ocho libros de oro para la guarnición y el frontispicio, además del lienzo, por un precio de 240 pesos de oro fundido de 13 quilates, de los cuales, 100 se le darían en pesos de ley y el resto en "géneros de la tierra", los cuales eran alpargates, conserva, azúcar y lienzo, lo que hace suponer que la tela usada como soporte y denominada "lienzo" pueda tratarse de un tejido de algodón hecho en la región, de ahí que se le llame "de la tierra"

Existen pinturas europeas de grandes artistas sobre batistas de algodón como es el caso de Albert Dürer o de Peter Brueghel ${ }^{61}$, pues se debe recordar que es una especie botánica existente en varios continentes aún antes de 1492 y su uso se remonta a milenios atrás en diversas culturas. En algunos casos se hacían telas mixtas de algodón, por ejemplo con cáñamo o lino.

Hay pruebas del uso de soportes de algodón en el Nuevo Reino de Granada durante el siglo XVII tanto en obras existentes aún como en notas documentales de la época. En muestras tomadas a pinturas del artista santafereño Gregorio Vásquez se hallaron, entre otros soportes, el denominado "lienzo de la tierra". Por estudios químicos y por tabla de color se identificó la presencia de blanco de plomo, bermellón, ocre, laca de garanza, lapislázuli,

57 Escobar, Hernando (1999): "Labateca le hizo el milagro a su patrona”. En: http://www.eltiempo.com/archivo/documento/MAM-888405 [20 de mayo de 2016].

${ }^{58}$ Ferreira, 2001: 461 y 462.

Gamboa Mendoza, Jorge Augusto: “Antes que falten los mayores en edad...”: Religiosidad indígena, memoria e identidad en el virreinato de la Nueva Granada a finales del siglo XVIII, texto inédito. Agradezco al antropólogo Jorge Gamboa compartirme su interesante artículo aún sin publicar.

${ }^{59}$ Cárdale, 1993: s/p.

60 Simón de Lora se obliga ante el cabildo de Vélez a pintar un lienzo con destino al altar del templo mayor de dicha ciudad, 1606, Archivo San Luis Bertrán - Orden de Predicadores, Bogotá (ASLBOP), Fondo Santander - Serie Asuntos Jurídicos, Índice 811, Subserie Contratos, Vol. 2/8/50/1.

Este documento se encuentra transcrito en: Vargas, 2012: 134 y 135.

${ }^{61}$ Doerner, 2005: 129 y 131. Este autor lamenta la hinchazón de las fibras de algodón encolada cuando se expone a altas temperaturas y humedad. En el caso de textiles muiscas han tenido la ventaja de estar en climas fríos sin estaciones.

Agradezco a la restauradora Patricia García Páez y a los maestros pintores Jorge Cortés y Gustavo Rico por sus apreciaciones técnicas sobre soportes de algodón. 
amarillo de plomo, negro de marfil, azurita, malaquita y verdigris, y en menor medida se hallaron cochinilla, rejalgar, oropimente, minio y esmalte y tierras en pinturas de caballete neogranadinas; entre los materiales de carga hay calizas, caolín, yesos y tierras rojas, ocres y amarillas que por su contenido de hematita y limonita podrían proceder de la Cordillera Oriental de Colombia ${ }^{62}$. El envío de telas para pintura no fue corriente entre los bienes registrados en la Casa de Contratación, mientras que sí aparecen pigmentos y medios ${ }^{63}$; los textiles que se exportaron a América eran usados en mayor medida en la sastrería.

Las mantas no solamente fueron soporte para imágenes religiosas, también se usaron para encargos oficiales de temas civiles como la pintura de las armas imperiales de Castilla e Inglaterra por encargo de la Real Audiencia con motivo de las honras fúnebres del emperador Carlos V llevadas a cabo en 1559, un año después del fallecimiento del monarca. Estas armas se hicieron por un precio de 17 pesos de oro, lo cual significaba una buena ganancia para el pintor porque el valor de una manta oscilaba entre 1,5 a 2 pesos de 20 quilates ${ }^{64}$. Hacia 1582, según testimonio del pintor Joan de Rojas, el corregidor y capitán Antonio Jove le encargó entre otras pinturas para la casa del Cabildo cuatro reposteros, cada uno formado por tres mantas blancas de la marca de algodón con las armas al temple y un poco de oro ${ }^{65}$.

\section{El cuerpo de las mantas}

Las mantas prehispánicas de algodón que se han estudiado hasta el momento han sido encontradas enterradas o en cuevas por lo que en su mayor parte fueron afectadas por la humedad y los hongos, se han hallado relativamente pocas y frecuentemente solamente fragmentos. Las mantas mejor conservadas provienen de territorios cálidos y secos. En algunos enterramientos se han encontrado elementos ligados al tejido como lo son volantes de huso de cerámica o piedra, agujas de madera o hueso y palos de cruce de telares. Junto al algodón también se han encontrado textiles realizados con cabello humano y fique utilizados para elaborar cuerdas de gran resistencia. Posiblemente los telares usados podían ser: telar de cintura, telar horizontal a nivel de piso y telar vertical, este último aún usado en Colombia y Ecuador ${ }^{66}$.

La especie de algodón identificada como la usada en los tejidos muiscas es Gossypium barbadense de la familia Malvacea ${ }^{67}$. A la bellota algodonera se le retiraban las semillas de los copos usando dos varas de madera para agrupar en mechas que luego se hilaban ${ }^{68}$. El algodón utilizado por los muiscas provenía de zonas de clima templado, por lo que debían conseguirlo a través de intercambio de maíz y papa con otros grupos indígenas ubicados en zonas menos altas que las del altiplano cundiboyacense. Las mantas tejidas por los muiscas eran cambiadas a los indios teguas por productos de estas tierras más cálidas como yuca, aguacate, ají y pescado $^{69}$.

Los hilos encontrados en textiles precolombinos colombianos presentan torsión en $\mathrm{S}$ y a veces en $Z$, que luego eran tejidos en telar. En cuanto a las características de la tela formada,

62 Rodríguez, Darío. "Materiales de pintura de caballete en la Nueva Granada”. Informe de investigación al Centro de Patrimonio. Bogotá, 1995. (Texto inédito, mecanografiado, consultado en el Ministerio de Cultura de la República de Colombia).

Agradezco al restaurador Pablo Vargas Álvarez la información sobre la existencia de este estudio.

63 Sánchez / Quiñones, 2009.

${ }^{64}$ Libros de acuerdos de la Real Audiencia de Santafé, 1559, AGN, Colonia, Real Audiencia de Cundinamarca, t. 50, f. 194r.

65 Pleito entre el pintor Joan de Roxas y el corregidor Antonio de Jove, 1590, AGN, Colonia, Residencias de Boyacá, t. 1, f. 598r. Documento transcrito en: Vargas, 2012: 99 - 127.

${ }^{66}$ Cortés, 1990: 63 y 64.

${ }^{67}$ Las dos especies americanas son Gossypium birsutum y Gossypium barbadense, mientras G. arboreum y $G$. herbaceum provienen de Asia y África. Ver: León, 2000: 115 - 120.

68 Tavera / Urbina, 1994: 39.

${ }^{69}$ Gamboa, 2013: 128, 420, 430. 
su urdido era corredizo, es decir sin remate ni costura en ninguno de los cuatro bordes; sus ligamentos podían ser tipo tafetán (tejido plano o sencillo o 1x1), teletón (plano o sencillo desigual, siendo el 2x1 al parecer el más común en textiles muiscas y guanes), tejido balanceado (el más común para tejidos pintados), esterilla (casi siempre al inicio y al final de la tela), cara de urdimbre, cara de trama, de estructura diversa y tejido doble; en cuanto a los orillos, se han encontrado planos, redondeados, ondeados, tubulares y en flecos. En general, se encuentran muchas similitudes con los textiles peruanos ${ }^{70}$. Al parecer la presión de los hilos de la trama se hacía con una herramienta hecha con hueso de venado, lo que la hacía más compacta y resistente ${ }^{71}$. (fig. 3) $\mathrm{Al}$ tratarse de un tejido artesanal se observan variaciones en las densidades de hilos por centímetro cuadrado entre muestras de tejidos de algodón prehispánicos y coloniales, que pueden producirse por el grosor de cada hilo y por la distinta fuerza que cada persona ejerce sobre el telar.

El tamaño de las mantas prehispánicas generalmente era de 1,80 m de largo x 1,20 m de ancho aproximadamente, medidas tomadas a partir de una de las pocas mantas que se ha hallado completa en Santander (Colombia) y que pertenece a la cultura guane pero que sugiere que las muiscas tenían un tamaño similar. Llama la atención que la longitud es casi la misma que tendrían las mantas coloniales. Las investigadoras Tavera y Urbina proponen que las dimensiones corresponden a un área donde se puede recostar un cuerpo tendido ${ }^{72}$, además el ancho corresponde a lo que los brazos del tejedor alcanzan a manejar en el telar.

Los tintes utilizados para colorear las mantas podían ser orgánicos como los extraídos del añil (Indigofera tinctorea), jagua (Genipa americana), achiote (Bixa orellana), trompeto (Bocconia frutescens), dividivi (Caesalpinia coriaria), barba de piedra (Usnea sp.), palo de Brasil (Caesalpinia echinata), chilco (Baccharis latifolia), palo amarillo (Haematoxylon campechianum), además de la púnciga, la batatilla y el insecto conocido como cochinilla (Dactylopius coccus) ${ }^{73}$. Otras muestras de tejidos han hecho proponer otra amplia variedad de pigmentos vegetales: Marrón oscuro del gamón (Dianella dubia); verde de las hojas de chilco (Baccharis latifolia) y yemas de caraote (Phaseolus vulgaris); azul a partir de flores de curubo (Passiflora sp.), flores de papa (Solanum tuberosum L. grupo Andigenum) y ramas de uvilla (Cestrumtinctorium); pepa de aguacate (Perseaamericana), añil (Indigoferasuffruticosa), frutas de jagua (Genipaamericana), frutas de sabuco o sauco (Sambucus nigra); amarillo de la raíz de lengua de vaca (Rumexcrispus), espino moral (Rubussp.), achiote (Bixaorellana), morcate (Miconiasp.) y azafrán de raíz (Escobediagrandiflora); rojo del cactus espinoso (Opuntiabonplandii), bija chica (Arrabidaeachica), punta de lanza (Vismiabaccifera), y barbas de piedra (Usnea sp. y Cladonia sp.). Otros pigmentos minerales usados fueron las tierras: azul de Siachioque, amarilla de Soracá y óxidos rojos de Sura. De origen animal se utilizaba sangre para obtener marrón y cochinilla para el rojo. La fijación de colores se hacía con tanino, lejía y mordientes como guarapo de aguacate, cal apagada, dividivi de tierra fría (Caesalpiniaspinosa), corteza de aliso (Alnusacuminata), barro cocido, orina y lejía de maderas ricas en taninos ${ }^{74}$.

Las mantas prehispánicas muiscas pintadas con pincel y con pluma presentan hilos finos de una densidad de 78 a 100 hilos por pulgada, la pintura no pasaba al otro lado de la tela, sus diseños son generalmente geométricos y posiblemente para hacerlos se reservó el soporte

70 Tavera / Urbina, 1994: 58, 64 - 78, 133 - 135. A diferencia de Tavera y Urbina, Emilia Cortés no encontró tejidos muiscas con cara de urdimbre, ver: Cortés, 1990: 64.

${ }^{71}$ Cortés, 1990: 64 y 65. Este artículo presentó interesantes imágenes de telares sacadas del libro Elprimer nueva coronica y buen gobierno de Guamán Poma de Ayala, 1615.

72 Tavera / Urbina, 1994: 83-87.

73 Tavera / Urbina, 1994: 30, 40, 48 - 53.

74 Cortés, 1990: 62.

Algunas actualizaciones de los nombres científicos de las especies fueron realizadas por la autora del presente artículo, quien así mismo, duda del uso de la naranja agria (Citrusaurantium), de la sábila (Aloevera) y de la hierbabuena (Menta piperita) que plantea como mordientes Emilia Cortés, ya que fueron especies introducidas en el periodo virreinal. 


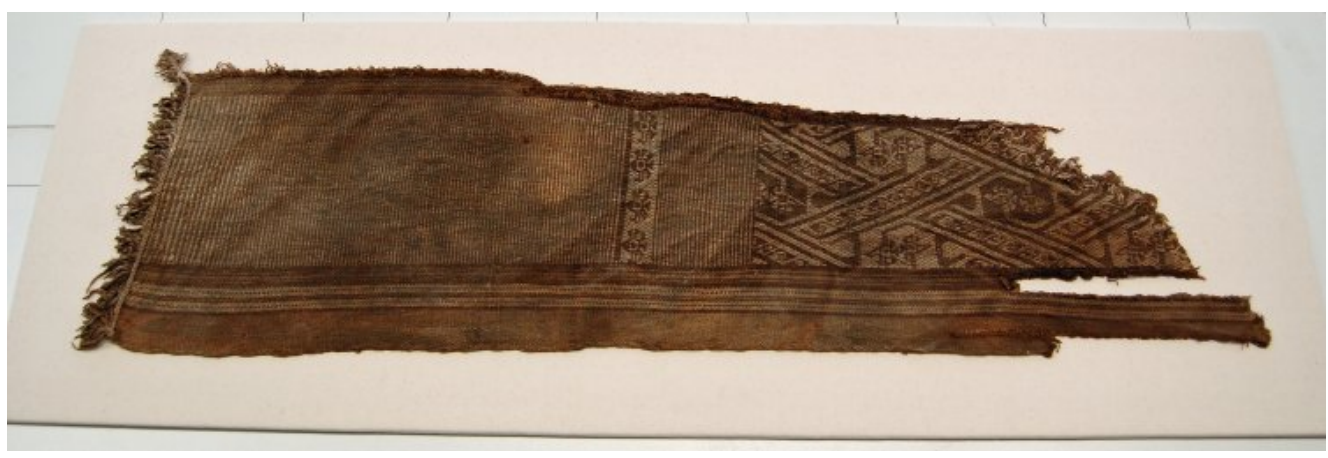

Fig. 4. Manta muisca. Tejido de algodón con hilos teñidos 92 x $26 \mathrm{~cm} 1300$ - 1400 d.C. Colección British Museum Número de registro Am1842,1112.4 (C) The Trustees of the British Museum

con cera o barro para hacerlo impermeable ${ }^{75}$. En documentos coloniales se hallan referencias a las "maures" que según explicó fray Pedro Simón eran fajas de algodón pintadas de colores con las que se ceñían las indias y que eran muy estimadas ${ }^{76}$. Existen también menciones a mantas "pachacates" que eran las coloradas ${ }^{77}$. También hubo mantas en las que el diseño se construyó a partir de hilos teñidos (fig. 4).

Las mantas de algodón se clasificaban como "finas" y "chingamanales" o "chingas", es decir las ordinarias. Con una carga de algodón se hacía una manta buena o fina, y con la misma cantidad de materia prima se hacían cuatro mantas chingas, las que fray Pedro Aguado describía como mal torcidas y peor tejidas. Una manta fina debía medir 2 varas y una sesma (1,81 m. aprox), aunque en 1555 se dio el caso de la petición de la disminución de un palmo en la medida de manta de la marca grande por parte de los indios de Ubaté ${ }^{78}$. Al ordenar fragmentos de mantas conservados en el Museo del Oro se plantearon dimensiones entre $1,81 \mathrm{~m}$ y $1,86 \mathrm{~m}$ de largo ${ }^{79}$.

\section{Los oficios alrededor de las mantas}

La producción de mantas no solamente obedeció a una demanda de telas para vestuario y uso doméstico sino a la imposición de tributos -a veces llamados "demoras"- por parte de los españoles a los indios y al papel de "mercancía-moneda" que fue común en la economía americana. Ésto, unido a la reducción de los indígenas en pueblos, al establecimiento de costumbres españolas y al control de las actividades de los adoctrinados en el catolicismo, generaron el establecimiento de obrajes para aumentar el número de mantas tejidas. En 1603, el obispo Bartolomé Lobo Guerrero exponía al rey que la eliminación del servicio personal que los indios ofrecían a los españoles era una gran equivocación puesto que la "natural inclinación" de los indios a eximirse de trabajar los dejaba ociosos y desocupados para así acudir a sus vicios, idolatrías y supersticiones, y con la posibilidad de juntarse con los pijaos, indios de guerra, y con los carares y areguíes, salteadores del Río Grande de la Magdalena. Además, la falta de labor en las minas de oro y plata, ingenios de azúcar, obrajes de lienzo y lana y en la ganadería causaría una disminución en las arcas reales. El religioso hacía énfasis en que dadas las malas costumbres de los indios, convenía que estuvieran ocupados con trabajo moderado para tenerlos "bien adoctrinados e instruidos en las cosas de nuestra santa

\footnotetext{
75 Tavera / Urbina, 1994: 116-122. Cortés, 1990: 65 - 66.

76 Simón, 1626: s/p. En la sección "Vocablos de este libro".

77 Londoño, 1990: 121.

${ }^{78}$ Gamboa, 2013: 409.

${ }^{79}$ Cortés, 1990: 73, 74.
} 
fe católica", y destacó que los indios ya no querían hilar y tejer como antes. Sin embargo, iniciaba su carta aclarando que los indios no debían sufrir maltrato ni vejaciones por parte de los españoles ${ }^{80}$.

La nueva organización administrativa y social supuso la introducción de tecnología europea. A los telares tradicionales prehispánicos se sumaron telares europeos, tornos, batanes, palmares para hilar, calderas de cobre para los tintes e instrumentos de hierro, además de una nueva materia prima que llegó con los conquistadores: la lana de oveja. En regiones de la zona andina se aprovechaba la lana de vicuña, alpaca y llama desde tiempos prehispánicos. Sin embargo, continuó la producción doméstica constituida por hiladores y tejedores, que en algunos casos entregaban telas para ser finalizadas en los obrajes ${ }^{81}$.

Los niños trabajaban como hiladores, existiendo una proporción de 10 a 12 niños por cada telar. Existen registros de talleres que tenían desde un solo telar hasta los que tenían nueve, y obrajes que alcanzaron a tener 80 niños indios laborando. La producción de ropas de la tierra generó varias líneas de trabajo: cultivadores para alimentar a la gente de los obrajes, pastores de ovejas, comercializadores de tintes, comerciantes, transportistas, carpinteros y herreros. Aunque a los indios se les pagaba por el trabajo, en el fondo, esta mano de obra era forzada y en ella el tributo y el salario no se compensaban y vivían endeudados, y a veces los tejedores además debían cumplir con labores del campo. Específicamente en la labor del tejido de algodón se encontraban los siguientes oficios: hiladores de torno, devanadores, urdidores, tejedores oficiales, tejedores asistentes, perchadores, canilleros, bataneros, tintoreros y picadores de palo Brasil, mientras que en el tejido de la lana, fuera de los mencionados, había otros trabajadores como apartadores, cardadores y batidores ${ }^{82}$.

Debemos preguntarnos si la exigencia de producción de mantas para la Corona, los horarios impuestos, el trabajo infantil, los castigos físicos y otras situaciones rompieron esa relación "íntima" que los muiscas tenían con el algodón como materia prima, ligada a enseñanzas legadas por sus deidades para el bien de sus pueblos. ¿Era el algodón como componente de los antiguos tunjos un material que a los muiscas les representaba divinidad como fácilmente lo suponemos del oro, la tumbaga y las esmeraldas? Si así era, lo más probable es que las condiciones laborales coloniales hubieran roto cualquier encanto con el suave y ancestral algodón.

El oficio de pintor de mantas fue preferido por los indígenas en lugar de las duras labores agrícolas. Quizá por esto, los caciques y capitanes de la encomienda de Nicolás de Sepúlveda en Gachancipá se quejaron en 1593 de los pocos indios labradores que había pues muchos se habían dedicado a la pintura, a la platería y a labrar oro ${ }^{84}$. La imposición de grandes cantidades de mantas a elaborar requirió implementar una desconocida forma de producción a gran escala para los indios a través de la cual no se dejaba la opción de tener tiempo libre que representara el riesgo de dedicarlo a alguna práctica idolátrica prehispánica, mientras los usos de las telas se iban adaptando a las nuevas formas de la vida virreinal. 1603.

80 Cartas y expedientes del Arzobispo de Santa Fe, 1603, AGI, Audiencia de Santa Fe, 226, nº 87,20 de mayo de

Agradezco al Dr. Francisco Herrera García por la aportación de este documento al presente estudio.

Para ampliar el tema del control de los indios a través de la doctrina y el trabajo, ver: López, 2001.

${ }^{81}$ Vanegas Durán, Claudia Marcela (2007): "La producción textil en el Nuevo Reino de Granada: Obrajes y tributación indígena en los Andes Centrales. Siglos XVI y XVII". En: http://www.icanh.gov.co/?idcategoria=6505 [3 de junio de 2016]: 3, 4, 22, 23.

82 Vanegas, 2007: 12, 13, 17, 18, 19.

${ }^{83}$ Por ejemplo, en el caso de la Nueva España se han estudiado y planteado hipótesis en torno a estas relaciones del hacedor, los materiales y las técnicas en el caso de los amantecas y la plumaria en la época posterior a la Conquista. Ver: Russo, 2014: 7, 92.

${ }^{84}$ Encomendero de Gachancipá y caciques deben recoger a los indios que se ausentan por sus oficios de aretsanos, 1593, AGN, Sección Colonia, Encomiendas, t. 20, año 1585, ff. 794r - 797v y AGNC, Sección Colonia, Tierras de Cundinamarca, t. 6, ff. 880rv. Documentos transcritos en: Vargas, 2012: 91 - 93, 129 - 130. 


\section{Conclusiones}

La facilidad de conseguir tejidos de algodón elaborado por los indios y los espaciados tiempos de la Flota de Indias hizo que rápidamente se adaptara como soporte pictórico para la creciente demanda de pintura en los pueblos de reducción de indios y en las ciudades recién fundadas.

La creación de obrajes supuso un gran cambio en la producción de telas tanto por la organización de talleres de trabajo como por la inclusión de máquinas y herramientas de origen europeo. A nivel social, el indígena se vio frente a una obligación de trabajo, rendimiento, pago de tributos y control de sus actividades que significó un cambio radical. De la prehispánica labor artesanal concebida como herencia de su dios Bochica, el indio pasó a trabajar como vasallo del rey.

Se deben diferenciar dos tipos de pintores: el pintor de manta y el maestro pintor que se dedicaba al caballete, murales, policromía de escultura y al dorado. El primero, conservó la técnica de pintura directa sobre la tela de algodón y durante algunas décadas mantuvo la iconografía propia de su tradición muisca, utilizando principalmente pigmentos de especies vegetales nativas con mordientes. $\mathrm{Y}$ el segundo, empleó las técnicas y materiales llegadas de Europa. Los diseños muiscas aparecen en obras de caballete y mural como parte del vestuario de retratos a indígenas. Los puntos en común que se observan en ambos tipos de pinturas es la preferencia de tejido plano balanceado y el uso de pigmentos minerales de extracción local.

Las pinturas de Labateca y de Chiquinquirá hacen pensar en el uso de temple encolado en las primeras obras hechas sobre tejidos de algodón en el periodo colonial, siendo de resaltar la tendencia de llegada de pinturas al temple (más que pinturas al óleo) a América desde Europa hasta mediados del siglo XVII, según los registros de la Casa de Contratación que conserva el Archivo General de Indias de Sevilla.

Las mantas muiscas monocromas y con diseños a pincel hicieron parte de la ornamentación de las primeras iglesias, apareciendo con frecuencia entre la segunda mitad del siglo XVI y las primeras décadas del XVII, época en la que se estaban dotando los templos de doctrina. La disminución de su presencia debió obedecer a:

1. La eliminación de diseños muiscas en lugares de culto para evitar la idolatría escondida entre las imágenes católicas.

2. La organización de talleres que surtían la demanda de obras pictóricas, escultóricas y de retablos de madera, desplazando así a la pintura mural, los retablos fingidos y la ornamentación con textiles.

Las mantas muiscas siguieron usándose como soporte para pintura de caballete pues la producción en los obrajes se mantuvo durante el periodo colonial, siendo llamado "lienzo de la tierra".

A través de un objeto ha sido posible ver un ejemplo del impacto de la inclusión de los reinos americanos a la Corona española. Las momificaciones y ofrendas dieron paso a los tributos para la Corona y a los milagros marianos pasando previamente por la extirpación de idolatrías. Del tunjo se pasó a la Virgen, en una compleja operación de estrategias, percepciones, respuestas y adaptaciones que deben ser estudiadas desde el mayor número de disciplinas posibles.

\section{Colofón}

El sincretismo de tradiciones, técnicas y materiales muiscas y españoles han continuado hasta nuestros días, visible en las artesanías de muchos pueblos colombianos. Quizás alguna vez un indio muisca soñó que sus tejidos cubrían a su diosa Chía, la luna, y así fue. En 1969 el Apolo XI fue forrado internamente por telas de lana virgen de ovejas de Boyacá y Santander (Colombia) tejidas a mano en Usaquén, el que fuera un pueblo de indios, hoy un barrio de Bogotá. Los mordientes del tejido, usados tradicionalmente en las ruanas, lo hacían incombustible y fijaban el color de manera duradera, además brindaban una sensación 
psicológica de bienestar a través de sus diseños, características que hicieron que Telas Huantay ganara la licitación de la NASA ${ }^{85}$.

85 Linares Gómez, Andrea (2009): “Telas colombianas ‘forraron' el Apolo 11; eran resistentes al fuego y por eso la Nasa las escogió”. En: http://www.eltiempo.com/archivo/documento/CMS-5654787 [15 de marzo de 2016]. 
Bibliografía

Abellán Pérez, J.: "Los paños de altar a través de los inventarios de la iglesia parroquial de Lebrija (siglos XV - XVI)". En: Littera scripta in honorem Prof. Lope Pascual Martinez: Murcia: Universidad de Murcia. (2002)

Acosta Luna, O.I.: Una manta más larga que ancha. Nuestra Señora de Chiquinquirá y la institucionalización de una imagen milagrosa en el Nuevo Reino de Granada, Memorias del 53 Congreso Internacional de Americanistas, 19 al 24 de julio de 2009. Ciudad de México: (CD). (2009).

Álvarez White, $\mathrm{M}^{\mathrm{a}}$ C.: Chiquinquirá. Arte y Milagro. Bogotá: Editorial Arco. (1986).

Cárdale de Schrimpf, M.: El arte del tejido en el país de Guane. Bucaramanga: Banco de la República. (1993).

Corradine Mora, M.: Vecinos y moradores de Tunja 1620 - 1623. Tunja: Consejo Editorial de Autores Boyacenses. (2009).

Cortés Alonso, V.: "Visitas a los santuarios indígenas de Boyacá". En: Revista Colombiana de Antropología, Vol. IX. Bogotá, (1960), pp. 199 - 273.

Cortés Moreno, E.: "Mantas muiscas". En Boletín Museo del Oro, Banco de la República, n 27, Bogotá, (1990), pp. $61-75$.

Correa Rubio, F.: El Sol del Poder. Simbología y politica entre los muiscas del norte de los Andes. Bogotá: Editorial Unibiblos - Universidad Nacional de Colombia. (2004).

Cummins, T.: "On the Colonial Formation of Comparison: The Virgin of Chiquinquirá, The Virgin of Guadalupe and cloth". En: Anales del Instituto de Investigaciones Estéticas, Universidad Nacional Autónoma de México, núms. 74 - 75, México, 67 - 74. (1999).

Chica Segovia, A.: "El simbolismo del templo cristiano presente en las iglesias de pueblos de indios del Altiplano Cundiboyacense construidas entre 1579 y 1616: la sencillez de lo mínimo necesario". En: López, María del Pilar / Quiles, Fernando (ed.)(2016): Visiones renovadas del Barroco iberoamericano, Vol. 1. Sevilla: Alcaldía Mayor de Bogotá, D.C., Universidad Nacional de Colombia, Universidad de los Andes y Universidad Pablo de Olavide, (2016), pp. 8 - 43.

Doerner, M.: Los materiales de pintura y su empleo en el arte. Barcelona, Editorial Reverte. (2005).

Ferreira Esparza, C. A.: "Nuestra Señora de las Angustias del pueblo de indios de Labateca. La doble cara de la cofradía colonial". En: Anuario de historia regional y de las fronteras, Universidad Industrial de Santander, Vol. 6, No 1, Bucaramanga, (2001), pp. 455-483.

Frassani, A.: "El templo doctrinero de Sutatausa y su pintura mural". En: Zalamea, Patricia (comp.): El patrimonio artístico en Cundinamarca. Casos y reflexiones. Bogotá: Gobernación de Cundinamarca y Universidad de los Andes, (2014), pp. 72 - 87.

Gamboa Mendoza, J. A.: El cacicazgo muisca en los años posteriores a la Conquista: del psibipqua al cacique colonial (1537 - 1575). Bogotá: Instituto Colombiano de Antropología e Historia. (2013).

Gamboa, J. A: Los muiscas y su incorporación a la monarquía castellana en el siglo XVI: nuevas lecturas desde la Nueva Historia de la Conquista. Tunja: Maestría de Patrimonio Cultural, Imprenta y Publicaciones UPTC. .(2016).

Gruzinski, S.: La guerra de las imágenes. De Cristóbal Colón a "Blade Runner" (1492 - 2019). México: Fondo de Cultura Económica. (1994).

Gruzinski, S.: "Mundialización, globalización y mestizajes en la Monarquía Católica". En: Chartier, Roger / Feros, Antonio (dir.) (2006): Europa, América y el mundo: Tiempos históricos. Madrid: Fundación Rafael del Pino, Fundación Carolina, Colegio Libre de Eméritos, Marcial Pons Ediciones Jurídicas y Sociales, (2006), pp. 217 - 237.

Herrera García, F. J./ Gila Medina, L.: "El retablo escultórico del siglo XVII en la Nueva Granada (Colombia). Aproximación a las obras, modelos y artífices”. En: Gila Medina, Lázaro (coord.) (2013): La consolidación del Barroco en la escultura andaluza e hispanoamericana. Granada: Ministerio de Economía y Competitividad y Universidad de Granada, (2013), pp. 301-368.

León, J:: Botánica de los cultivos vegetales. San José de Costa Rica: Editorial Agroamérica. (2000).

Londoño, E.: "Mantas muiscas. Una tipología colonial". En: Boletín del Museo del Oro, Banco de la República, No 27, Bogotá, (1990), pp. 121 - 126. 
Langebaek, C. H.: "Resistencia indígena y transformaciones ideológicas entre los indios muiscas de los siglos XVI y XVII”. En: Gómez Londoño, Ana María (2005): Muiscas. Representaciones, cartografías y etnopolíticas de la memoria. Bogotá: Pontificia Universidad Javeriana, (2005), pp. 25 - 51.

López, M.: Tiempos para rezary tiempos para trabajar. La cristianización de las comunidades muiscas durante el siglo XVT. Bogotá: Instituto Colombiano de Antropología e Historia. (2001).

Romero Sánchez, G.: "Los pueblos de indios en Nueva Granada: Trazas urbanas e iglesias doctrineras" (Tesis doctoral). Granada: Universidad de Granada. (2008).

Romero Sánchez, G. / Ruíz Gutiérrez, A.: "Patrimonio oriental en los templos doctrineros de los pueblos de indios neogranadinos". En: Cuadernos de Arte. Universidad de Granada. Vol. 41, Granada, (2010), pp. $111-130$.

Romero Sánchez, G.: “Alonso de Narváez, pintor andaluz establecido en Tunja”. En: Andalucía y América. Patrimonio artístico. Granada: Editorial Universidad de Granada. (2011).

Russo, A.: The untranslatable image. A Mestizo History of the Arts in New Spain, 1500 - 1660. Austin: University of Texas Press. (2014).

Sánchez, J. Mª / Quiñones, Ma D.: "Materiales pictóricos enviados a América en el siglo XVI", En: Anales del Instituto de Investigaciones Estéticas, UNAM, No 95, México, (2009), pp. 45 - 67.

Simón, fray Pedro,: Primera parte de las Noticias historiales de las conquistas de Tierra Firme en las Indias Occidentales. Cuenca: Casa de Domingo de la Iglesia. (1626).

Simón, fray Pedro: Noticias historiales de las conquistas de Tierra Firme en las Indias Occidentales, Tomo IV. Bogotá: Casa Editorial de Medardo Rivas. (1892).

Simón, fray Pedro: Noticias historiales de las conquistas de Tierra Firme en las Indias Occidentales, Tomo III. Bogotá: Biblioteca Banco Popular. (1981).

Siracusano, G.: "El cuerpo de las imágenes andinas. Una mirada interdisciplinaria". En: Anales del Instituto de Investigaciones Estéticas, UNAM, No 94. México, (2009), pp. 155 - 162.

Tavera de Téllez, G. / Urbina Caycedo, C.: Textiles muiscas y guanes, Bogotá: Universidad de los Andes. (1994).

Tobar y Buendía, P. de: Verdadera histórica relación del origen, manifestación y prodigiosa renovación por sí misma y Milagros de la imagen de la sacratísima virgen María madre de Dios nuestra Señora del Rosario de Chiquinquirá. (Edición facsimilar, 1986). Bogotá, Instituto Caro y Cuervo. (1694).

Valenzuela Avaca, E.: "Kerigma: preguntas teóricas en torno a la primera evangelización de América (Antillas, 1510 - Nueva España, 1524)”. En: Historia Crítica, nº58, Bogotá, (2015), pp. 13-32.

Vargas Murcia, L. L.: Del pincel al papel: fuentes para el estudio de la pintura en el Nuevo Reino de Granada (1552 - 1813). Bogotá: Instituto Colombiano de Antropología e Historia. (2012).

Zamora, Alonso de, Fray O.P.: Historia de la Provincia de San Antonio del Nuevo Reino de Granada del Orden de Predicadores. Barcelona: Imprenta de Joseph Llopis. (1701). 